\title{
Imitating Jesus, yes - BUt Which Jesus? A CRITICAl ENGAGEMENT With THE ETHICS OF RichaRd BURRIDGE IN IMITATING JESUS: AN INCLUSIVE APPROACH TO NeW TESTAMENT ETHICS (2007)
}

\author{
Author: \\ Jonathan A. Draper

\begin{abstract}
Affiliation:
${ }^{1}$ School of Religion and Theology, University of KwaZulu-Natal, South Africa
\end{abstract}

Correspondence to: Jonathan A. Draper

e-mail:

draper@ukzn.ac.za

\section{Postal address:}

School of Religion and Theology, University of KwaZulu-Natal, Private Bag X101, Scottsville, Pietermaritzburg, 3209, South Africa

\section{Keywords:}

New Testament ethics; historical Jesus; Bible under apartheid; imitating Jesus; Burridge

\section{Dates:}

Received: 16 Apr. 2009

Accepted: 03 June 2009

Published: 05 Aug. 2009

How to cite this article: Draper, J.A., 2009, 'Imitating Jesus, yes - but which Jesus? A critical engagement with the ethics of Richard Burridge in Imitating Jesus: An inclusive approach to New Testament ethics (2007)', HTS Teologiese Studies/Theological Studies 65(1) Art. \#164, 5 pages. DOI: 10.4102/hts.v65i1.164

\section{This article is available} at: http://www.hts.org.za

(c) 2009. The Authors. Licensee: OpenJournals Publishing. This work is licensed under the Creative Commons Attribution License.

\section{ABSTRACT}

This paper examines the attempt by Richard Burridge in his recent book, Imitating Jesus: An inclusive approach to New Testament ethics (2007), to build an engaged Christian ethics starting with the historical Jesus but taking full account of the insights into the perspectives of the four gospels in their own right, based on their genre as Greek bioi. While Burridge's approach is applauded and regarded as a major step forward, it is critiqued here on his selectivity in his presentation of the results of two decades of research into the Jesus of history. Burridge's selection of the South African experience in the struggle against apartheid as his 'test case' is also questioned, since the issues in such struggles for justice appear more straightforward to outsiders than they do to insiders and his analysis raises more questions than it answers.

\section{INTRODUCTION}

In his recent major work, Imitating Jesus: An inclusive approach to New Testament ethics (2007), Burridge sought to build on his early studies on the genre of the gospels as being formally close to the Greek genre of bioi (Burridge 1992; 2000; 2004; 2005). Since these have as one of their central features the stimulation of the readers or hearers in respect of the imitatio of the central figure in their noble life and death, it follows that their words or teachings are only one aspect of the whole. The gospels as bioi of Jesus have as their goal not so much teaching as the promotion of the imitation of Jesus by their narrative of his life, works and heroic death and of his words.

Firstly, I would like to welcome the publication of this book from a number of points of view, not least because of the provocative riposte of its title to the traditional imitatio Christi, Jesus before Christ, an issue already highlighted by Nolan (1976). I was convinced many years ago by the argument by Sanders (1985) that research into the Jesus of history should start with his deeds rather than his words and Burridge's work on the genre of the gospels certainly adds further weight to this point of view.

Secondly, I welcome the insistence on keeping the connection between the ethics of the New Testament and their relevance and application to today, however difficult this may be. In contrast to the majority of works on the ethics of the New Testament, which have been cautious about the possibility of reconstructing an ethics of Jesus himself and even more cautious about seeing any relevance between the ethics of the New Testament and the modern world, Burridge has set out from the start to address the question of Christian praxis.

Thirdly, the use of South Africa as a 'test case' also proves intriguing, stimulating and disturbing to those scholars in South Africa who live their academic lives as active and engaged participants within this context, provoking both strong agreements and disagreements.

\section{Outline of argument}

Burridge's study begins with a welcome overview of recent scholarship on Christian ethics, giving due weight to the various traditions of interpretation. This is a good summary in a short space and highlights what Burridge, rightly in my opinion, has identified as lacunae in research, namely inadequate attention to the historical Jesus as the starting point for Christian ethics and the reluctance of scholars to apply their insights to ethical issues of today. Furthermore, an issue obviously close to his own heart, he has critiqued the failure to address the question of genre, since the New Testament 'is simply not an ethical treatise or book of moral instruction' (Burridge 2007:16). In an appropriate gesture, given his determination to include the question of applied New Testament ethics, Burridge has set out the person context of his project, his own academic pilgrimage and his long-standing connection with Africa through teaching on this continent and through tutoring students at King's College, London. This, together with the use of the Bible by both sides in the apartheid struggle, accounts for the use of South Africa as a 'test case'.

Burridge has rejected the image of the gospels as clear windows to the historical Jesus and the communities that produced them, as well as the idea of the gospels as mirrors simply reflecting the concerns of the reader, preferring rather the image of the gospels as stained glass, which allows indistinct vision of the scene beyond them and the dim reflection of the reader, but of which the main point

is the picture within the glass, how the artist has composed it in a limited space and used the conventions about depicting the hero or saint, what has been included and what has been left out.

(ibid. 2007:25)

His insistence on attention to the question of genre, namely the gospels as bioi, as lives of someone intended to be imitated, has led him to see that 'each gospel's Christology is the key to its interpretation' (ibid. 30). Not the teaching of Jesus alone (such as the Sermon on the Mount or Plain) as much as the actions and noble death of the hero represent the call to mimesis, to ethical action in imitation. While 
Jesus did proclaim the eschatological imperative of the imminent coming of the kingdom, at the heart of this is an ethic of response leading to incorporation into a new community aimed at the restoration of Israel and a radical interim ethic. At the heart of it all is the command to love God and one's neighbour, including one's enemy, as God's mercy impels one to forgive in response. Jesus did set out rigorous ethical instructions on money and possessions, on war, on violence and on the state. These, however, do not provide a legal code but 'exaggerated standards to inspire us to the best we can be' (ibid. 2007:59). However, the teaching must be set in the context of 'Jesus' table fellowship of eating with tax collectors and sinners', of his healing of outsiders and of failures (ibid. 2007:63). Jesus foresaw himself in death as a martyr who would be vindicated by God and symbolised in the bread and wine of the Last Supper the gift of his life for sinners:

He not only accepted them, ate and drank with them, but also healed them from disease and impurity and probably saw his own death as "for" them ... Jesus' attitude and actions towards sinful people are as important as his teaching in establishing his ethic.

(ibid. 2007:68)

The other side of this is that Jesus 'expects a total response' (ibid. 200:70) to their open acceptance by God that this symbolised, as they imitated his life in the discipleship to which he called them (ibid. 2007:70).

In a lengthy analysis of the ethics of Paul, Burridge has found that Paul too was concerned with the concept of 'imitation' (of him as he imitated Christ). Paul did not view Jesus as primarily a teacher who gave words but one whose deeds called for imitation and discipleship. Paul too emphasised openness to sinners and outsiders and the admission of sinners and outsiders into the community. Paul too stressed the imminence of the end and provided an interim ethics rather than a moral code. He also addressed the pressing moral questions of money, possessions, violence and the state. Thus Burridge has emphasised the continuity rather than the discontinuity between the ethics of Jesus and the ethics of Paul.

This pattern is followed through in Burridge's rich treatments of the four evangelists and their 'stain glass' depictions of Jesus. In all of them, each in its own way, the importance of imitating Jesus, of the sovereign rule of God, of the double love command, of an open, inclusive community and of 'eating with tax collectors and sinners' are emphasised. The pressing ethical questions concerning 'family, marriage, divorce and children, money and possessions, power, leadership and the state' all appear under this 'radical' aspect (ibid. 2007:185). Mark stressed suffering, Matthew 'being truly righteous', Luke God's 'universal concern' for the peoples of the world and John 'teaching the truth in love'. In this way, Burridge has been able to bring the gospel tradition and Paul into a synthesis with the historical Jesus and to find a consistent ethical perspective set in the richly varied colours of the different texts. The same lens has then been applied to the ethical problem of the evil system of apartheid in a largely Christian country. This is no mean feat. Indeed, at times, it feels to me a little like a conjuring trick. Nevertheless, in setting out the following concerns, I do not mean to minimise the importance of Burridge's achievement, which surely opens up a new approach to New Testament ethics.

\section{Historical Jesus as starting point}

I would like to begin with Burridge's presentation of the Jesus of history, since this is, in a way, crucial to his ethical approach. I follow Burridge in seeing a connection between the eschatological nature of Jesus' preaching of the breaking in of God's reign now and the response of those who heard the call to repentance as central to the ethics of Jesus. It is hard to conceive of the Jesus phenomenon without assuming that he was calling people to something radically new and exciting in a situation of crisis. Without excluding the elements of the wisdom tradition in the teaching of Jesus, it seems to me right to argue that the prophetic pronouncement of the 'day of the Lord' is more fundamental to his identity and purpose. But why then adhere to the double love command as the definitive aspect of this proclamation? Surely this is not the centre of the prophetic tradition? Justice is the centre of the prophetic tradition - the justice of God, which cannot endure the oppression and exploitation of God's people and which prevails against the wicked in God's chosen moment. Justice cannot, of course, be separated from the love of God, since love, in turn, underlies God's just concern for the cries of the widows and the orphans and the oppressed poor. Love cannot be separated from the justice of God either, since human beings are the objects of God's justice. In later rabbinic tradition, justice and love came to be seen as the two faces of God (current already in the time of Rabbi Akiba and Rabbi Ishmael, according to Segal [1977:151-154]). Justice also provides the link between ethics and eschatology because of the question of theodicy: God cannot be a loving God if he allows injustice to flourish on earth, if God allows the righteous to suffer indefinitely. This is the point at which the 'fuzzy love', of which ethicists are rightly afraid, becomes focused and cutting love. The justice and love of God provide the basis for a human ethics centred on justice and love. Even a cursory examination of the deeds and words of Jesus show that this twin emphasis underpins his ethics, both lived and spoken, inasmuch as we can discern its historical dimensions.

This then leads to my concern with Burridge's placing of commensality at the centre: Jesus' table fellowship with 'tax collectors and sinners', which translates into an open, inclusive community as the basis for a new ethical theory and practice. But, again, open commensality with no concern for issues of justice, in other words repentance and restitution, as shown by Zacchaeus in, for example, Luke 19:8-9, would simply be a 'sell-out' on the part of Jesus. Burridge's confident assertion (Burridge 2007:6268 ) that Jesus had 'eaten with sinners' and that this is central to understanding his movement remains open to question, despite its popularity with those scholars who see Jesus as a kind of ancient, boundary-breaking hippy (Crossan 1991). The common meal that Jesus shared with his disciples does seem to have been an important symbol and to have come to be used (probably by his followers after his death) as a way of understanding his action in Jerusalem and his death on the cross. However, Horsley (1993:212-223), whom Burridge has strangely cited in support of his understanding (Burridge 2007:63, note 105), has strongly challenged the traditional 'friend of sinners' interpretation, which resonates so strongly with the sola gratia of the Protestant Reformation. Precisely because of its potential use by pietistic interpretations of Jesus, Horsley has refused to concede that Jesus was specially accommodating to tax collectors, sinners and prostitutes: 'There is simply little or no direct evidence in the gospel tradition that Jesus held table fellowship or otherwise associated with "sinners"' (Horsley 1993:217). An accusation of something is not the same as evidence of behaviour:

that Jesus is accused of associating with toll collectors and sinners is not evidence that he actually did so. Indeed, readers or hearers of the gospel traditions would have assumed the accusation against Jesus to be false.

(ibid. 2007:221)

In the same way as the followers of John the Baptist, so the disciples of Jesus understood themselves as 'repentant and forgiven sinners now participating in and responsible for the new life made possible by God's initiative in offering the kingdom' (ibid. 2007:222). Jesus understood himself as God's agent in renewing local community and, in this way, in providing an alternative vision of the rule of God to the vision of God's rule underlying the claims of the élite, which inevitably supported their own financial and power interests.

Not everyone accepts this hypothesis by Horsley as I do (Draper 1994) but I have laboured this question because of its importance in Burridge's overall hypothesis. It is a sign of his scant attention to the socio-economic analysis that has been an important and contested aspect of recent research into the Jesus of history. 
So the understanding of Jesus as a Galilean peasant is, for me, important because it challenges the meaning of the 'open, inclusive community' that is so important in Burridge's ethical hypothesis. Jesus was a peasant leader of a peasant movement. He did not exactly take an 'option for the poor', as many engaged scholars, myself included (Draper 1991), once thought, since he was already poor (Stegemann 1984), and probably a member of a peasant family that had lost its land and so was forced into the more menial and despised work of carpentry (Van Aarde 2001). The way in which he viewed those who were unable through poverty, necessity and labour to comply with aspects of the Torah and were hence branded 'sinners' would not have been the view of the élite but the view of the peasantry. The 'open, inclusive community' was an aspect of the 'solidarity of the poor' that brought him into conflict with the ruling élite and their retainer class of lawyers. It does not necessarily mean that those accused of being 'sinners' or called disparagingly 'people of the land' because of their inability to comply with the purity rules of the Judaean temple state were guilty of any immoral action. One has to take account of the concept of 'on-stage, offstage', where the élite and their retainer class monitored what was said on-stage against the 'official transcript', while the peasants discussed their 'hidden transcript' off-stage (Herzog 1994; Horsley 2004; Scott 1990).

Some of the puzzling and offensive teaching of Jesus could be interpreted against this background, where the peasants sought to insert their 'hidden transcript' into the 'official transcript' in ways that deconstructed it without being actionable. Jesus' teaching on Roman taxation is a good example of this dynamic, if I may paraphrase it:

Give to Caesar what belongs to Caesar ... nothing, let him take back his damn idolatrous coinage with its claim to the divinity of Caesar ... and give to God what belongs to God . . . everything, especially in eretz Yisrael the land of God's covenant with Israel!

(cf. Draper 1999)

So the code was understood by the peasants and half-understood in an uneasy way by the élite, since the 'great tradition' and the 'little tradition' are flip sides of each other. While Jesus did teach in the market-places of the village, where all could hear him, it seems that he undertook his most important acts and teaching in closed, protected environments where the powerful could not silence or patrol him. Jesus' chosen envoys (or apostles) were furthermore sent out in secrecy, forbidden to preach in the open, instructed to remain in one household and to eat what was put before them, utilising Exodus typology (Mark 6:6-56). It was in this way that the message of God's kingdom was passed by word of mouth in the peasant underground.

Jesus also spoke to people who responded in deserted places, where the authorities could not follow easily, going there by boat, while the crowds came in small groups, and, after symbolic feeding, he immediately left, again by boat (Draper 1995). Jesus' triumphal entry into Jerusalem and temple action were carefully planned (Mark 11:1-2) and he again left the city immediately afterwards to stay with peasant sympathisers, probably in Bethany, before the authorities could react with their inevitable violence (Mark 11:11). Then there was Jesus' secret coded entry into Jerusalem for Passover in the upper room (Mark 14:12-16) and his immediate exit to the secret, open-air venue outside this dangerous city $(14: 26)$. Only treachery from inside the movement could penetrate such well-executed secret planning, as always in peasant movements, where peasants protect their own and usually respond with ignorance to interrogation by the élite (Hobsbawm 1981).

All this is part of the narrative transcript of the actions of Jesus on which Burridge has placed so much emphasis and which Sanders has also highlighted, although Sanders would be horrified by my particular interpretation, I am sure, because he does not take these kinds of socio-economic data into account. As Sanders has argued, Jesus' prophecy in respect of the temple is one relatively certain historical detail to emerge from historical reconstruction and, while Sanders is more cautious on Jesus' triumphal entry into Jerusalem, I would add this to the relatively certain details of Jesus' historical life and death. The combination of these two events seems to me to have led inexorably to Jesus' death and to provide both the motivation for and the explanation of this. Indeed, it was a planned and significant action on the part of Jesus and therefore key to any ethical interpretation of his life in the bioi of all four gospel writers. In other words, I would argue for more specific focus on and direction towards Jesus' action in seeking to 'bring in the reign of God' than happy meals with sinners.

\section{Elephants and ethics today}

Here, I am not arguing that this interpretation is necessarily correct, even though I am convinced by it myself. Rather, the discussion highlights the extent to which historical Jesus research is inevitably a process of constructing a new bios of Jesus. The historical reconstruction offered by the historian is an attempt (whether consciously or unconsciously, indeed, implicitly more often than not) to persuade the reader to a mimesis, whether positively in imitating Jesus or negatively in rejecting his life as futile and pathological and so living differently either as an Übermensch (Friedrich Nietsche) or as a brave new scientific atheist (Richard Dawkins). These should also be seen as the mimesis arising out of new narrative bioi.

The inevitable social and economic questions and power dynamics in the 'open, inclusive community' are critical if it is to be a model for Christian ethics today and for the same reasons. One does not hear of Jesus inviting scribes to give his people Hebrew Scripture studies or to discuss the finer implications of the Torah with his disciples in small, intimate groups. Their Torah discussions were instead a matter of public controversy not dissimilar to the head-on confrontations between apartheid Biblical propagandists and their anti-apartheid Biblical opponents seeking to undermine the 'official transcript' of apartheid South Africa. Not polite and, indeed, antithetical to the refined sensitivities of academic élite readings! Who does not squirm when reading the attacks on the Pharisees in Q? ('Woe to you Pharisees, hypocrites ...'). The same goes for Jesus' relationship with the Herodians ('Tell that old fox ...', Lk 13:32) and the Sadducees. We do not hear about Jesus' relationship, if this existed, with the Essenes. Jesus may occasionally have accepted invitations to dine with Pharisees but he used such an occasion to humiliate his host, who had humiliated him (Lk 7:36, if this goes behind Luke's redaction). Furthermore, there might have been some disaffected members of the élite or retainer class in Jesus' inner circle, as is often the case in new religious movements and as was the case in apartheid South Africa (with Beyers Naudé, Wolfram Kistner and others, for whom we should be grateful), but they were accepted among the poor only on Jesus' terms: 'Go sell all that you have' or, as could have been phrased in our South African struggle: Leave your desire to dominate and control at the door or do not come in at all.

This issue of hegemony in relationships between the poor and the powerful was and is a major one in South Africa both in the time of the struggle and today. Burridge has chosen to highlight the apartheid struggle as a 'test case'. I therefore think that I can be frank, without being descriptive. First a few points about the struggle:

- Apartheid did not arise from a mistaken interpretation of Scripture. Instead, it arose from the dynamics of empire and the socio-economic forces in colonial society, from the imperative to maintain group identity and control in circumstances of isolation from the imperial centre. The analysis by Douglas (1966) and her discussion of the body as a social map are far more powerful in explaining the origin and evolution of a small, isolated group threatened through the integrity of its boundaries in terms of pressure from a larger group than are the various modes of reading the Bible. 
- The legitimation of apartheid was not undertaken in agonised sincerity by well-meaning academics but was part of a propaganda machine orchestrated by the Broederbond, of which many (of course, not all) Afrikaans academics were members. If it was indeed undertaken in agonised sincerity by some, then it was the product of false consciousness on their part. The provision of alternative interpretations of Scripture by proponents of the struggle for justice - and there were significant voices (such as those of Beyers Naudé and the Christian Institute and, later, those associated with the Kairos Document of 1985) - made no impact on hegemonic discourse until the system began to collapse under military, social and economic pressure. It is interesting that Burridge has made no mention of the hermeneutics and exegesis of the Christian Institute or the Kairos scholars, such as Nolan in his God in South Africa: The Challenge of the Gospel (1988). The Kairos Document did come late in the apartheid years but it was the culmination of 40 years of resistance hermeneutics.

- Attempts to engage with these propagandists for apartheid through exegesis on the part of progressive academics were undertaken but these were not heeded because the methods of interpreting the Bible by the academics were directed by social forces and not by intellectual debate. Those courageous Afrikaans academics who did listen to the voices of protest were frequently harassed and sometimes even silenced.

- The security forces attempted to monitor and suppress such academic discourse by enrolling members of the security police to attend classes as theology students and to pass on sensitive information about participants, to the extent that, in some academic settings, it became necessary for informers to be excluded from graduate seminars for the protection of progressive graduate students, such as Frank Chikane, Director of the Institute for Contextual Theology. ${ }^{1}$ Public and hidden discourse applied in the same way then as I believe it did in Jesus' time when those with power and those without power interacted. The discourse of the oppressed became a 'hidden transcript' undertaken off-stage.

- One possible difficulty with the concept of 'open, inclusive community' reading as a fundamental principle of the ethical reading of the Bible arising from the experience of apartheid is highlighted by the statement that

such counter-cultural reading communities must never become fellowships of the like-minded. Our approach to the New Testament ethics requires the interpretative community always to be open and diverse, inclusive of those who might disagree with us, but who are still making their response of discipleship as we follow Christ together.

(Burridge 2007:394)

- Admittedly, Burridge was responding to the counterargument by Katongole (2001) to postmodernism but it does raise questions in situations of crisis and danger, such as existed in the heyday of apartheid in South Africa. Burridge has already argued that the use of scriptural narratives to provide examples for today was common on both sides of the apartheid debate' (Burridge 2007:382). My own over-sensitive memory senses an implication, not intended by Burridge, that those who interpreted the Bible from the progressive side were part of the problem because their exegesis was not done in 'open, inclusive community' with the apartheid theologians. ${ }^{2}$ Does this mean that their resistance should not have been undertaken, that their exegesis and ethics were inappropriate because others were not listening, that they should have risked the lives of political activists by opening them up to betrayal? ${ }^{3}$ In situations of crisis, 'fellowships of

1.This happened at, for example, the School of Theology at the University of Natal, which had publicly adopted a manifesto based on the Kairos Document.

2.It should be noted that Burridge rejected any such interpretation of his model in his response to this paper at the ethics group session on his book at the SBL Annual Conference in Boston in November 2008.

3.Agents of apartheid South Africa's intelligence branches infiltrated both Christian activist groups and university classrooms, and unguarded discussions in their presence could lead to the arrest and interrogation of participants. the like-minded' may be a necessary aspect of prophetic witness. Would Jesus have invited Herod's secret service to the private houses where his apostles were spreading his message of the imminent arrival of the reign of God? Jesus warned his disciples when they were sent out in the face of Herod's repression to stay in one house where they found someone willing to listen and not to go from house to house (Mark 6:10 and the Q parallel in Luke 10:7). Would he have sent a note informing the high priests and Sadducees what he was planning in the temple? Would he have invited the scribes and Pharisees to the upper room? Subversive secrecy may be necessary in situations of crisis.

At the heart of the Kairos Document critique of the usual church position was the attempt to reach a middle way between apartheid and its advocates and the liberation struggle. Such 'church theology' argued that the government was wrong but that the armed response of the liberation movement was also wrong and that what was needed was mediation for the acceptance of 'Jesus' position', this position differing from both approaches, it being one of the 'gentle Jesus meek and mild' (the Goldilocks effect, Balcomb 1993). This position evolved as Third Way Theology in South Africa (many South African church folk seizing on the well-intentioned work by Wink (1987) to underpin this, even though Wink himself was arguing for active nonviolent resistance). The 'mediating' position of compromise that characterised mainline church response was the particular target of contextual theology and therefore implicitly of contextual biblical studies. The Kairos Document characterised the three positions as 'state theology', 'church theology' and 'prophetic theology'. In a situation of injustice, God does not call on his people to be neutral but to take the side of struggle against injustice and to adopt a prophetic stance against the state and its propagandists. Burridge was aware of this and it does not undermine the central principle of his ethical hermeneutic, that of inclusive community. My intention in this rhetorical detour is to point to the way in which hegemony limits the possibility of inclusive rhetorical community.

This brings me to the question of contextual biblical studies, which Burridge has used as his 'cap stone' case study. Contextual biblical studies arose out of this context of the struggle against apartheid. Gerald West has developed this in a particular direction at the Institute for the Study of the Bible, now the Ujamaa Centre, but it was initiated by the first director, our colleague Professor Gunther Wittenberg, under the influence of his experiences of base-community readings of the Bible in South America, especially as by Carlos Mestes and Paulo Freire (1970). It continues to carry that legacy proudly. It has naturally also continued to evolve but it was originally designed both to conscientise and to create space for the poor and marginalised in the dangerous context of struggle against an oppressive and murderous government in South Africa, as in Latin America. It was initially conceived as an interventionist strategy but the problem of the hegemony and agency of the intellectual subsequently arose and does arise inevitably in this case: educated, well-off and ideologically orientated people sitting with poor and uneducated people! Can there be an inclusive and egalitarian Bible reading community here? Freire has indeed been critiqued along these very lines by, for example, James Gee (1996). However empowering your pedagogy, it is still being controlled by you and it is you who sets the agenda. West has attempted to move the boundaries further in favour of the reading community of the poor with his concept of 'reading with', in which the 'grass roots intellectual' (if such a Gramskian person actually exists) abdicates power, humbly making resources available and stepping back to listen to the responses of the poor and powerless, to be influenced by them and to communicate their wisdom and plans of action to a waiting world (Cardinal 1982).

Yes. And contextual biblical study has indeed achieved some real good and has had and continues to have interesting results. 
What I say here should therefore not be misconstrued as hostile in that I am not convinced that it qualifies as 'open, inclusive community' in the sense that it involves sending fieldworkers and university students to conduct workshops in response to invitations from particular communities and, in some cases, to solicited invitations. These reading experiences do not usually involve continuing, ongoing connection between the academy and the poor, although there have certainly been attempts at this. The texts, questions and processes are furthermore usually determined by the UC and not by the poor. It does, in fact, have a quite specific ideological orientation and goal. Some (such as Beverley Haddad and Sarojini Nadar) have even overtly used the methodology as an interventionist strategy, even as West seeks to minimise the agency and power persona of the fieldworker. But campaigns such as Worker Sunday and the Tamar Campaign against Violence on Women are explicitly interventionist - and rightly so. The question raised here has been raised powerfully in some harsh criticism by Nadar and Maluleke (2004). The harshness of their critique of self-interest and false consciousness may go further than warranted and may be unnecessarily ad hominem, but Nadar and Maluleke do raise valid questions concerning hegemony and agency. West's method may work best when used in educated and equal groups, which is why it was so successful at the recent Lambeth Conference (2008), as has been the case with other groups of academics in the United States and Europe. It could even be argued that it is more celebrated outside South Africa than inside it. The presence of powerful, educated people in a community of the poor and marginalised can easily create an implicit new 'public transcript and a new off-stage "hidden transcript"', a new hidden discourse of the powerless, in other words what is said and done when the contextual biblical study fieldworkers have gone home, because the powerless want access to resources. Power is slippery. Indeed, West is fully aware of these dynamics and problems and engages with them in his writing and in his praxis. This, however, is a far cry from Burridge's enthusiastic espousal of the method.

None of the foregoing should be seen as lessening my admiration for what Burridge has attempted and achieved in his effort at a broad and holistic ethical reading of Jesus, Paul and the gospels and in his insistence that this should be done in the context of praxis. Indeed, the model is particularly helpful in the African context, where many academics still seek to hold together Jesus, Bible and contextual application in a meaningful way (West 2000). I simply wonder whether it is wise to choose a case study from somewhere else, where there may a difference in the way that the dynamics are perceived by an outsider and by an insider. Burridge, to his credit, is aware of this question and does acknowledge that his motivation is that there is an 'elephant in the room' in Western academia. He hopes, in this way, to find a neutral space where the application of ethics is less complicated. It may, all the same, have been preferable for him to have tackled his own elephant head-on, since, in South Africa, we also have elephants in the room!

\section{REFERENCES}

Balcomb, A., 1993, Third Way Theology: Reconciliation, revolution and reform in the South African church during the 1980s, Cluster Publications, Pietermaritzburg.

Burridge, R.A., 1992, What are the Gospels? A comparison with Graeco-Roman biography, Cambridge University Press, Cambridge.

Burridge, R.A., 2000, 'Gospel genre, Christological controversy and the absence of Rabbinic biography: Some implications of the biographical hypothesis', in D.G. Horrell \& C.M. Tuckett (eds.), Christology, controversy and community: New Testament essays in honour of David Catchpole, pp. 137-156, Brill, Leiden.

Burridge, R.A., 2004, What are the Gospels? A comparison with Graeco-Roman biography, 2nd edn., Eerdmans, Grand Rapids.
Burridge, R.A., 2005, 'Who writes, why and for whom?', in M. Bockmuehl \& D.A. Hagner (eds.), The written Gospel, pp. 99-115, Cambridge University Press, Cambridge.

Burridge, R.A., 2007, Imitating Jesus: An inclusive approach to New Testament ethics, Eerdmans, Grand Rapids.

Cardinal, E., 1982, The Gospel in Solentiname I-II, Orbis, Maryknoll.

Crossan, J.D., 1991, The Historical Jesus: The Life of a Mediterranean Jewish Peasant, HarperCollins, San Francisco.

Douglas, M., 1966, Purity and danger: An analysis of the concepts of pollution and taboo, Routledge, London.

Draper, J.A., 1991, 'Christ the worker: Fact or fiction?', in J.C. Cochrane \& G.O. West (eds.), The threefold cord: Theology, work and labour, pp. 121-141, Cluster Publications, Pietermaritzburg.

Draper, J.A., 1994, 'Jesus and the renewal of local community', Journal of Theology for Southern Africa 87, 29-42.

Draper, J.A., 1995, 'Wandering radicalism or purposeful activity? Jesus and the sending of messengers in Mark 6:656', Neotestamentica 29(2), 187-207.

Draper, J.A., 1999, 'Give to Caesar the things that belong to Caesar and give to God the things which belong to God, Mark 12:13-17, and Jubilee 2000', Bulletin for Contextual Theology 6(2), 18-22.

Freire, P., 1970, Pedagogy of the oppressed, Continuum, New York.

Gee, J.P., 1996, Social linguistics and literacies: Ideology in discourses, 2nd edn., Taylor \& Francis, London.

Herzog, W.R. II., 1994, Parables as subversive speech: Jesus as pedagogue of the oppressed, Westminster/John Knox, Louisville.

Hobsbawm, E., 1981, Bandits, Pantheon, New York.

Horsley, R.A., 1993, Jesus and the spiral of violence: Popular Jewish resistance in Roman Palestine, 2nd edn., Fortress Press, Minneapolis.

Horsley, R.A., (ed.), 2004, Hidden transcripts and the arts of resistance: Applying the work of James C. Scott to Jesus and Paul, SBL, Atlanta.

Katongole, E.M., 2001, 'African hermeneutics and theology in the twenty first century: On surviving postmodernism', in M. Getui, T. Maluleke \& J. Ukpong (eds.), Interpreting the New Testament in Africa, pp. 253-273, Acton, Nairobi.

Nadar, S. \& Maluleke, T.S., 2004, 'Alien fraudsters in the white academy: Agency in gendered colour', Journal of Theology for Southern Africa 120, 5-17.

Nolan, A., 1976, Jesus before Christianity, David Philip, Cape Town.

Nolan, A., 1988, God in South Africa: The Challenge of the Gospel, David Philip, Cape Town.

Sanders, E., 1985, Jesus and Judaism, SCM, London.

Scott, J.C., 1990, Domination and the arts of resistance: Hidden transcripts, Yale University Press, New Haven.

Segal, A.F., 1977, Two powers in heaven: Early Rabbinic reports about Christianity and Gnosticism, Brill, Leiden.

Stegemann, W., 1984, 'Vagabond radicalism in early Christianity? A historical and theological discussion of a thesis proposed by Gerd Theissen', in W. Schottroff \& W. Stegemann (eds.), God of the lowly, pp. 148-168, Orbis, New York.

Van Aarde, A., 2001, Fatherless in Galilee: Jesus as a child of God, Trinity Press International, Harrisburg.

West, G.O. \& Dube, M.W. (eds.), 2000, The Bible in Africa: Transactions, trajectories and trends, Brill, Leiden.

Wink, W., 1987, Violence and non-violence in South Africa: Jesus' Third Way, New Society Publishers, Philadelphia. 